\title{
Mycobacterium bovis BCG in metastatic melanoma therapy
}

\section{Martha Lucia Ruiz Benitez ${ }^{1}$ - Camila Bonnemann Bender ${ }^{1}$ - Thaís Larré Oliveira ${ }^{1}$ Kyle M. Schachtschneider ${ }^{2,3,4}$. Tiago Collares ${ }^{1} \cdot$ Fabiana Kömmling Seixas ${ }^{1}$ (1)}

Received: 24 May 2019 / Revised: 22 July 2019 / Accepted: 26 July 2019 / Published online: 12 August 2019

(C) Springer-Verlag GmbH Germany, part of Springer Nature 2019

\begin{abstract}
Melanoma is the most aggressive form of skin cancer, with a high mortality rate and with 96,480 new cases expected in 2019 in the USS. BRAF $F^{V 600 E}$, the most common driver mutation, is found in around $50 \%$ of melanomas, contributing to tumor growth, angiogenesis, and metastatic progression. Dacarbazine (DTIC), an alkylate agent, was the first chemotherapeutic agent approved by the US Food and Drug Administration (FDA) used as a standard treatment. Since then, immunotherapies have been approved for metastatic melanoma (MM) including ipilimumab and pembrolizumab checkpoint inhibitors that help decrease the risk of progression. Moreover, Mycobacterium bovis Bacillus Calmette-Guerin (BCG) serves as an adjuvant therapy that induces the recruitment of natural killer $\mathrm{NK}, \mathrm{CD} 4^{+}$, and $\mathrm{CD}^{+} \mathrm{T}$ cells and contributes to antitumor immunity. BCG can be administered in combination with chemotherapeutic and immunotherapeutic agents and can be genetically manipulated to produce recombinant $\mathrm{BCG}(\mathrm{rBCG})$ strains that express heterologous proteins or overexpress immunogenic proteins, increasing the immune response and improving patient survival. In this review, we highlight several studies utilizing rBCG immunotherapy for MM in combination with other therapeutic agents.
\end{abstract}

Keywords Bacillus Calmette-Guérin $\cdot$ Recombinant BCG $\cdot$ Immunotherapy $\cdot$ Antitumor activity $\cdot$ Skin cancer

\section{Introduction}

Melanoma is the most aggressive form of skin cancer, representing $4 \%$ of all dermatological cancers. A total of 96,480 new cases of melanoma will be diagnosed, and 7230 deaths are expected in 2019 in the USA (Siegel et al. 2019). Its etiology is multifactorial, being associated with both environmental and genetic factors. $B R A F^{V 600 E}$ is the most common mutation, being observed in around 50\% of melanomas and contributing to tumor growth, angiogenesis, and metastatic

Fabiana Kömmling Seixas

seixas.fk@gmail.com

1 Laboratory of Cancer Biotechnology, Technology Development Center, Federal University of Pelotas, Pelotas, Rio Grande do Sul, Brazil

2 Department of Radiology, University of Illinois at Chicago, Chicago, IL, USA

3 Department of Biochemistry \& Molecular Genetics, University of Illinois at Chicago, Chicago, IL, USA

4 National Center for Supercomputing Applications, University of Illinois at Urbana-Champaign, Urbana, IL, USA progression (Garnett and Marais 2004; Haass et al. 2004). Current treatments for advanced melanoma include chemotherapeutic and immunotherapeutic strategies, such as dacarbazine (DTIC), vemurafenib, interferon, interleukin 2 (IL-2), imiquimod, and checkpoint inhibitors. In addition, a number of recent studies are identifying new therapeutic strategies and targets for reducing melanoma's metastatic potential (Orgaz and Sanz-Moreno 2013; Mattia et al. 2018). One of these treatments is Mycobacterium bovis Bacillus CalmetteGuerin (BCG). BCG is an attenuated strain that has been used as an immunotherapeutic agent for melanoma and superficial urothelial carcinoma (Begnini et al. 2015; Maruf et al. 2016). Nowadays, wild-type BCG and recombinant strains are used in combination with chemotherapeutic and immunotherapeutic agents to enhance the immune response and tumor regression (Stewart and Levine 2011) (Fig. 1).

An improved understanding of the biological, genetic, molecular, and immunologic factors contributing to the progression of metastatic melanoma (Brandner and Haass 2013; Griewank et al. 2014; Shtivelman et al. 2014) may help identify novel therapeutic strategies (Ribas et al. 2011; Sullivan and Flaherty 2014). In addition, advanced proteomic technologies may be useful for detection and analysis of proteins 

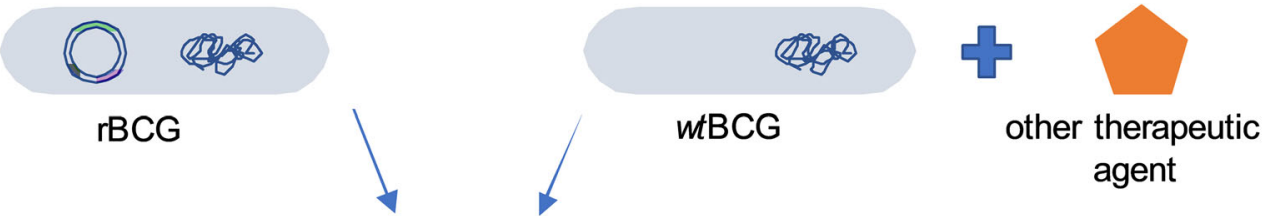

Intralesional administration
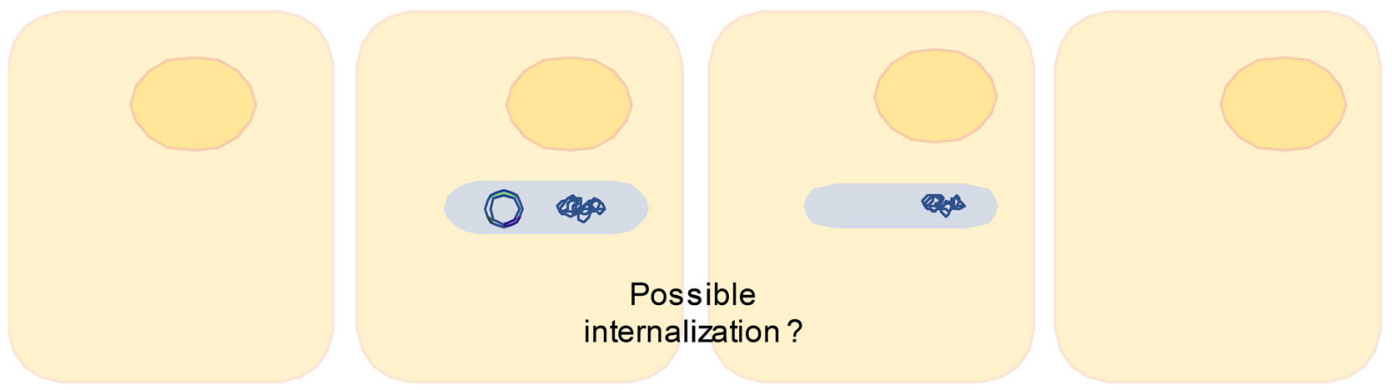

Melanoma cells internalization?

\section{Release of cytokines \\ Activation and recruitment of immune cells Regulation of adhesion molecules Polarization of tumour microenvironment}

Fig. 1 Administration of wild-type or recombinant BCG strains alone or in combination with a chemotherapeutic or immunotherapeutic agent enhances immune responses and tumor regression in melanoma patients

involved in melanoma progression (Findeisen et al. 2009; Bougnoux and Solassol 2013). In this review, we highlight several studies utilizing BCG immunotherapy in combination with other therapeutic agents for the treatment of metastatic melanoma.

\section{Melanoma}

Melanoma is a neoplastic disorder caused by the malignant transformation of normal melanocytes and represents the most aggressive type of skin cancer (Bandarchi et al. 2010). Most cases originate in the skin, followed by the eyes and mucous membranes. Melanoma is associated with environmental factors and patient demographics, such as lighter skin tone, sun sensitivity, presence of atypical nevi, multiple freckles, people with weakened immune systems, and family history of melanoma (Gallagher et al. 2005; Bishop et al. 2007). Its increasing incidence is due to different ethnicity, geographical location, and excessive exposure to ultraviolet radiation combined with its high metastatic potential which has resulted in a significant increase in mortality
(Gallagher and Lee 2006; Ali et al. 2013; Arnold et al. 2018).

Melanoma is subdivided into four different types: superficial spreading melanoma ( $70 \%$ of melanomas), nodular melanoma (15-30\%), acral lentiginous (5-10\%), and lentigo malignant (5\%) (Goldstein 2001; Bastian 2014).

Deregulation of the MAPK, PI(3)K-AKT, P16INK4A/ $\mathrm{Rb}$ ), and Wnt/b-catenin signaling pathways is observed in metastatic melanoma and has been implicated in its etiopathogenesis and invasive behavior (Orgaz and SanzMoreno 2013; Alegre et al. 2014; Gurzu et al. 2018). Somatic mutations in the BRAF gene are observed in 40 $60 \%$ of melanoma cases (Curtin et al. 2005; Abildgaard and Guldberg 2015). The most commonly observed mutation results in the substitution of lysine for valine (V600K mutation) (Long et al. 2011; Lovly et al. 2012) and is responsible for the activation of the MAPK pathway, which regulates normal cell growth and survival (Shinozaki et al. 2007; Flaherty and McArthur 2010; Roskoski 2010). Other genes commonly mutated in melanomas include NRAS (15-30\%) (Gorski et al. 2005), $C D K 4, C D K N 2 A$ (observed in 20 to $40 \%$ of families with melanoma susceptibility) (Puig et al. 2005; Potrony et al. 2015), p16, PTEN, AKT1, MAP2K1, MAP2K2, MAP3K5, 
and $M A P 3 K 9$. In addition, a number of DNA methylation changes have been reported (Hodis et al. 2012; Nikolaev et al. 2012; Stark et al. 2012). These mutations and epigenetic alterations trigger and promote the secretion of growth factors that contribute to cell proliferation, angiogenesis, alterations in the extracellular matrix, cytoskeletal organization, and metastasis (Haass et al. 2004; Orgaz and Sanz-Moreno 2013) to various organs such as the lungs, liver, brain, and bones (Leong 2003).

Melanoma diagnoses are made by dermatoscopy examination and advanced digital computer imaging techniques following the morphologic features summarized by the asymmetry, border, color, diameter, and elevation (ABCDE), which are confirmed by biopsy and histopathological examination. This process also allows for melanoma staging and prognostic, as well as TNM (tumor, node metastasis) classification for detection of distant metastases (Abbasi et al. 2004; Balch et al. 2009; Ciudad-Blanco et al. 2014; Lattanzi et al. 2019).

\section{Therapies for metastatic melanoma treatment}

Treatment for metastatic melanoma (MM) is mostly based on systemic therapy, although radiotherapy and surgical treatments are also used. However, current treatments have not resulted in significant improvements in patient survival due to adverse effects (Smith et al. 2007). Surgery is mostly used for resection of distant metastases (Luther et al. 2019). Radiation therapy can be used as adjuvant therapy for systemic therapy; however, some patients with symptomatic metastases can benefit from radiotherapy (Bhatia et al. 2009).

The first systemic therapy used for MM treatment is the cytotoxic chemotherapeutic agent Dacarbazine (DTIC). DTIC is an alkylate agent and is the first chemotherapeutic agent approved for MM by the US Food and Drug Administration (FDA) in 1975. Another treatment that had been approved for MM treatment in the USA is interleukin-2, an immunostimulatory cytokine involved in $\mathrm{T}$ cell proliferation. Interleukin-2 trials have demonstrated a 15 to $20 \%$ response rate for MM patients (Schwartzentruber et al. 2011); however, this drug failed to demonstrate survive prolongation (Garbe et al. 2011). Other cytokines being used to treat MM include interferon-alpha (Luther et al. 2019), the first cytokine to demonstrate activity in MM, with tumor response ranging from 10 to $20 \%$ (Schadendorf et al. 2009).

Since 2011, ten new agents have been approved by the FDA, including targeted therapies, immunotherapies, cancer vaccines, and other small molecules that can act as monotherapies or in combination (Simeone and Ascierto 2017; Luther et al. 2019). Ipilimumab is an IgG1 monoclonal antibody targeting cytotoxic $\mathrm{T}$ lymphocyte antigen 4 (CTLA-4). Treatment with ipilimumab was the first treatment to demonstrate a survival advantage for patients with MM (Wolchok et al. 2010). Other checkpoint inhibitors approved for MM include the programmed death 1 (PD-1) inhibitors nivolumab and pembrolizumab (Albertini 2018). These PD1 inhibitors were first approved for patients with melanoma refractory to vemurafenib and/or ipilimumab. Atezolizumab, avelumab, and durvalumab are PD-L1 inhibitors that have also been approved for use in MM patients with advanced melanoma (Arulananda et al. 2018; Callahan et al. 2018; Hogan et al. 2018).

Talimogene laherparepvec (TVEC) is the only oncolytic virus approved for melanoma treatment (Luther et al. 2019). Another immunotherapeutic agent is allovectin-7 (velimogene aliplasmid) which is well tolerated, reduction in tumor size, and seems to be safe for the treatment of stage III or IV melanoma (Gonzalez et al. 2006; Bedikian et al. 2010; Sloot et al. 2016).

Drugs targeting altered mitogen-activated protein kinase (MAPK) pathway signaling-commonly disrupted in MM due to BRAF ${ }^{V 600 E}$ mutations - have been approved form MM treatment, including dabrafenib and vemurafenib (Heakal et al. 2011; Hauschild et al. 2012). Other approaches to treat MM include combination therapies. Combination therapies can be a solution for the treatment of $\mathrm{MM}$ that is resistant to individual therapies (Srivastava and McDermott 2014; Gazzé 2018). However, one potential problem regarding the use of combination therapies is increased toxicity. The combination of vemurafenib and cobimetinib, dabrafenib and trametinib, or encorafenib and binimetinib have become standard treatments for MM patients carrying the $B R A F^{V 600 E} \mathrm{mu}-$ tation (Ribas et al. 2016). Immunotherapies can also be combined. The most well-established and studied combination is ipilimumab and nivolumab (Hodi et al. 2016).

Despite recent advances, these therapies still have limitations including low response rates, adverse side effects, and resistance, especially for anti-PD-1/PD-L1 checkpoint inhibitors (Broussard et al. 2018). For these reasons, novel treatment strategies for MM are currently being developed (Olszanski 2014; Arulananda et al. 2018; Sullivan et al. 2018) to improve targeted therapy through identification of new targets for MM and combine current and future drugs (Mitchell 2003; Finn et al. 2012; Broussard et al. 2018).

\section{Bacillus Calmette-Guérin}

BCG is an attenuated Mycobacterium bovis strain developed by Albert Calmette and Camille Guérin that is widely used as a vaccine to protect against tuberculosis (TB) (Hart and Sutherland 1977; Dietrich et al. 2003) and has also been used as the first-line immunotherapy for intravesical treatment of superficial urothelial carcinoma (Ahn et al. 2014; Begnini et al. 2015; Maruf et al. 2016), resulting in reduced recurrence 
and progression (Kresowik and Griffith 2009; Askeland et al. 2012; Morales et al. 2015; Donin et al. 2017). However, BCG administration can cause adverse side effects including hematuria, irritation, local inflammation, and cystitis (Koya et al. 2006). The exact mechanism of action is unknown but it involves BCG binding to the fibronectin of the bladder wall followed by its internalization via macropinocytosis and presentation of BCG antigens to T cells (Lattime 1992; Zhao et al. 2000; Redelman-Sidi et al. 2013), causing tumor cell killing through signaling via the Toll-like receptors (TLR) 2, 3, 4, and 9 , resulting in cytokine secretion and induction of the local inflammatory response (Miyazaki et al. 2006; Suttmann et al. 2006; Naoe et al. 2007).

There are several BCG modifications being used for immunotherapy and vaccination (Yuan et al. 2010; Zheng et al. 2015). BCG is sub-classified in different strains (Leung et al. 2008; Hayashi et al. 2009; Liu et al. 2009), and BCG exhibits anti-proliferative activities and results in the production of cytokines including IL-6 and IL-8 (Secanella-Fandos et al. 2013). Also, BCG has been genetically manipulated to secrete recombinant proteins (Borsuk et al. 2007; Begnini et al. 2013; Oliveira et al. 2017), foreign antigens from parasites, bacteria, and viruses (Bastos et al. 2009), and pro-inflammatory cytokines including IL-2, IL-8, and IL-18 that can enhance humoral and cellular immune responses (Biet et al. 2002; Luo et al. 2003; Luo et al. 2004).

rBCG::Ag85B-IFN- $\gamma$ has been used in C57BL/6 mice to enhance immune responses and induced tumor necrosis factor TNF- $\alpha$ and IFN- $\gamma$ expression (Liu et al. 2017). In addition, recombinant BCG::Rv2645 has been shown to improve dendritic cell (DC) antigen presentation and enhance Th1/Th17 immune responses against tuberculosis (Luo et al. 2018). The pantothenate auxotroph strain of Mycobacterium bovis BCG (BCGDpanCD) expressing HIV-1 Gag, Gp120, and RT induces a production of IL- 2 and TNF- $\alpha$ by $\mathrm{T}$ cells (Chapman et al. 2013). Another recombinant BCG strain ( $\triangle$ ureC::hly) expressing a heterologous protein of Listeria monocytogenes has been shown to trigger production of caspases, IL-18, and IL-1 $\beta$ (Saiga et al. 2015). A similar study with $\Delta$ ureC hly+ BCG was reported by Desel et al. (2011) and some vaccines with this construction are being tested for clinical efficacy to demonstrate their immunogenicity and safety (Nieuwenhuizen et al. 2017).

As an alternative to BCG, Mycobacterium vaccae (M. vaccae) has been shown to be safe, well tolerated, and results in long-term survival in patients with MM (Cananzi et al. 2013). In addition, the use of Mycobacterium indicus pranii $(\mathrm{Mw})$ for the treatment of melanoma is being studied due to its ability to inhibit the matrix metalloproteinase (MMP-9), inhibiting melanoma tumor cell growth, and reducing invasiveness and metastatic potential (Halder et al. 2017).

\section{BCG combination in melanoma treatment}

BCG is used as an immunotherapeutic agent for the treatment of cutaneous MM. It is commonly administered alone or in combination with an autologous tumor cell vaccine or drug by intralesional injection (Sloot et al. 2016) for different stages of melanoma, resulting in regression of local and regional tumors and improved patient survival (Lotem et al. 2002; Triozzi et al. 2011). There are many different BCG-based combination therapies currently in use for the treatment of melanoma (Table 1). One of the most common combinations is BCG with DTIC which results in a $36.5 \%$ increase in the 10-year survival rate for stage II melanoma patients (Cascinelli et al. 1989). Additional combinations such as BHD (hydroxyurea with DTIC), BHD plus BCG, and DTIC plus BCG have been tested in patients with disseminated $\mathrm{MM}$, resulting in overall response rates of $31 \%, 27 \%$, and $18 \%$, respectively (Costanzi et al. 1982). Even, the use of BCG and retinoids such as vitamin A palmitate and tretinoin have been shown to display antitumor activity for MM (Meyskens Jr. 1982).

In a study for patients with stage IV melanoma, the use of the allogeneic cancer vaccine canvaxin ${ }^{\mathrm{TM}}$ in combination with BCG following complete resection resulted in antitumor immune responses and a 5-year overall survival rate of $39 \%$ compared with that of $20 \%$ for unvaccinated patients (Hsueh et al. 2002). This combination also increased the number of cytokine-producing CD4+ T cells, which correlated with overall survival (Hsueh et al. 2004). Faries et al. (2017) performed the same study on 246 stage IV melanoma patients treated with canvaxin ${ }^{\mathrm{TM}}$ and $\mathrm{BCG}$ following complete surgical resection and compared the results with 250 patients treated with BCG/placebo administered by intradermal injection. These results showed no improvement in patient outcomes and a 5year survival rate of 34.9 months for patients treated with canvaxin $^{\mathrm{TM}}$ and $\mathrm{BCG}$ compared with that of 39.1 months for patients treated with BCG/placebo. A similar study using BCG in combination with DTIC reported that this combination caused mild toxicity and was well tolerated, but did not improve patient outcomes compared with BCG alone (Agarwala et al. 2004).

Polyvalent vaccines have been shown to increase IgM responses and enhance the humoral immune response in patients with stage II melanoma, resulting in improved survival (DiFronzo et al. 2002). CancerVax has also been shown to induce an increase in TA90-IC antibodies in patients with advanced melanoma resulting in prolonged survival. TA90IC is an antigen expressed on melanoma cells that serve as a prognostic marker, with higher TA90-IC levels present in patients with stage IV melanoma (Tsioulias et al. 2001). Another study reported immunization of MM patients with either smallpox (vaccinia) or BCG, showing that the vaccination reduced the risk of death and prolonged patient survival (Kölmel et al. 2005). 
Table 1 Combination BCG treatments for melanoma

\begin{tabular}{|c|c|c|c|c|c|c|}
\hline BCG strain & BCG dose & Population & Drug/vaccine & $\begin{array}{l}\text { BCG } \\
\text { administration }\end{array}$ & Main results & Reference \\
\hline Connaught & $\begin{array}{c}\text { BCG plus } 100,000 \\
\text { units of vitamin }\end{array}$ & $\begin{array}{l}49 \text { patients } \\
\text { with stage I } \\
\text { and stage II }\end{array}$ & $\begin{array}{l}\text { BCG } \\
\text { BCG + high-dose } \\
\quad \text { vitamin A }\end{array}$ & $\begin{array}{l}\text { BCG by } \\
\text { scarification }\end{array}$ & $\begin{array}{l}\text {-The difference in relapse-free survival in the } \\
\text { two groups was not statistically significant } \\
(p=0.27) \\
\text {-Vitamin A was well tolerated }\end{array}$ & $\begin{array}{r}\text { Meyskens } \\
\text { Jr. } 1982\end{array}$ \\
\hline Connaught & $\begin{array}{l}6 \times 10^{8}(\text { range } 4-8 \times \\
\left.10^{8}\right)\end{array}$ & $\begin{array}{l}386 \text { patients } \\
\text { with } \\
\text { disseminat- } \\
\text { ed } \\
\text { malignant } \\
\text { melanoma }\end{array}$ & $\begin{array}{l}* \text { BHD (betahistine } \\
\text { dihydrochloride) } \\
\text { BHD } \\
\text { BHD + BCG } \\
\text { DTIC+BCG }\end{array}$ & $\begin{array}{l}\text { BCG by } \\
\quad \text { scarification }\end{array}$ & $\begin{array}{l}\text {-In patients older than } 60 \text { years of age, the } \\
\text { response rate appeared higher in the BCG } \\
\text { groups, but this was not statistically } \\
\text { significant } \\
\text {-BHD plus BCG and DTIC plus BCG } \\
\text { showed an overall response rate of } 27 \% \\
\text { and } 18 \% \text {, respectively }\end{array}$ & $\begin{array}{l}\text { Costanzi } \\
\quad \text { et al. } \\
\quad(1982)\end{array}$ \\
\hline Pasteur & $6 \times 10^{8} \mathrm{CFU}$ & 196 patients & $\begin{array}{l}\text { *DTIC, Dacarbazina } \\
\text { DTIC } \\
\text { DTIC + BCG } \\
\text { DTIC + Corynebacterium } \\
\quad \text { parvum }\end{array}$ & $\begin{array}{l}\text { BCG by } \\
\text { scarification }\end{array}$ & $\begin{array}{l}\text {-The duration of response was longer with } \\
\text { DTIC + BCG treatment but the difference } \\
\text { was not statistically significant } \\
\text {-In nonresponders, survival was less than } 7 \\
\text { months }\end{array}$ & $\begin{array}{l}\text { Veronesi } \\
\text { et al. } \\
\text { (1984) }\end{array}$ \\
\hline Pasteur & $75 \mathrm{mg}$ & $\begin{array}{l}668 \text { patients } \\
\text { with stage II }\end{array}$ & $\begin{array}{l}\text { DTIC } \\
\text { BCG } \\
\text { BCG + DTIC }\end{array}$ & $\begin{array}{l}\text { BCG by } \\
\text { scarification }\end{array}$ & $\begin{array}{l}\text {-The patients that were initially non-reactive } \\
\text { to BCG developed skin reactivity after } 6.7 \\
\text { + } 9 \text { BCG vaccinations. } \\
\text {-Survival rate of patients submitted to BCG } \\
\text { treatment was } 34.3 \% \text {, and patients who } \\
\text { received BCG and DTIC was } 36.5 \% \\
\text { overall and } 30.1 \% \text { event-free survival }\end{array}$ & $\begin{array}{l}\text { Cascinelli } \\
\text { et al. } \\
\text { (1989) }\end{array}$ \\
\hline Connaught & $3.4 \times 10^{8} \mathrm{CFU}$ & $\begin{array}{l}18 \text { patients } \\
\text { with stage } \\
\text { III or stage } \\
\text { IV }\end{array}$ & $\begin{array}{l}\text { Mitumomab (BEC-2) } \\
\text { KLH (keyhole limpet } \\
\text { hemocyanin) } \\
\text { BEC2 conjugated to KLH } \\
\text { and mixed with BCG } \\
\text { (BEC2-KLH/BCG) }\end{array}$ & $\begin{array}{r}\text { Intradermal } \\
\text { injection }\end{array}$ & $\begin{array}{l}\text {-Four patients developed anti-GD3 IgM anti- } \\
\text { bodies as a result of immunization with } \\
\text { BEC2-KLH/BCG } \\
\text {-Thirteen of the patients were free of } \\
\text { melanoma, resulting in a } 78 \% \text { survival rate }\end{array}$ & $\begin{array}{r}\text { Yao et al. } \\
\text { (1999) }\end{array}$ \\
\hline Tice & $10^{7} \mathrm{CFU}$ & $\begin{array}{l}20 \text { patients } \\
\text { with stage } \\
\text { IV }\end{array}$ & $\begin{array}{l}\text { Autologous melanoma } \\
\text { vaccine and BCG + } \\
\text { rhGM-CSF }\end{array}$ & $\begin{array}{r}\text { Intradermal } \\
\text { injection }\end{array}$ & $\begin{array}{l}\text {-Twelve patient }(60 \%) \text { had progression of } \\
\text { disease during treatment } \\
\text {-Two patients }(10 \%) \text { showed partial response }\end{array}$ & $\begin{array}{l}\text { Leong } \\
\quad \text { et al. } \\
\text { (1999) }\end{array}$ \\
\hline Tice & $\begin{array}{l}\text { CancerVax was } \\
\text { administered } \\
\text { with BCG at } 8 \times \\
10^{6} \mathrm{CFU}\end{array}$ & $\begin{array}{l}219 \text { patients } \\
\text { with stage } \\
\text { II, III, or IV }\end{array}$ & CancerVax + BCG & $\begin{array}{r}\text { Intradermal } \\
\text { injection }\end{array}$ & $\begin{array}{l}\text {-CancerVax inhibited the metastatic process } \\
\text { by activating cytotoxic T cells } \\
\text {-There was an increased IgM response } \\
\text {-TA90-IC levels were significantly higher for } \\
\text { patients with stage IV melanoma than for } \\
\text { patients with stage II }\end{array}$ & $\begin{array}{l}\text { Tsioulias } \\
\text { et al. } \\
\text { (2001) }\end{array}$ \\
\hline Tice & $\begin{array}{l}2.7 \text { to } 10.8 \times 10^{6} \\
\text { CFU }\end{array}$ & $\begin{array}{l}150 \text { patients } \\
\text { with stage } \\
\text { IV }\end{array}$ & Canvaxin vaccine $+\mathrm{BCG}$ & $\begin{array}{r}\text { Intradermal } \\
\text { injection }\end{array}$ & $\begin{array}{l}\text {-The incidence of recurrence was } 69 \% \text { in } \\
\text { vaccinated patients and } 88 \% \text { in } \\
\text { nonvaccinated patients }\end{array}$ & $\begin{array}{l}\text { Hsueh } \\
\text { et al. } \\
\text { (2002) }\end{array}$ \\
\hline Tice & $8 \times 10^{6} \mathrm{CFU}$ & $\begin{array}{l}83 \text { patients } \\
\text { with stage II }\end{array}$ & $\begin{array}{l}\text { Canvaxin, polyvalent } \\
\text { vaccine }(\mathrm{PV})+\mathrm{BCG}\end{array}$ & $\begin{array}{r}\text { Intradermal } \\
\text { injection }\end{array}$ & $\begin{array}{l}\text {-PV induced cellular and humoral immune } \\
\text { responses, there was an increase in } \\
\text { anti-TA90 immunoglobulin (IgM) associ- } \\
\text { ated with decreased, recurrence, and im- } \\
\text { proved survival }\end{array}$ & $\begin{array}{l}\text { DiFronzo } \\
\quad \text { et al. } \\
\text { (2002) }\end{array}$ \\
\hline $\begin{array}{l}\text { BCG was } \\
\text { purchased } \\
\text { from } \\
\text { Pasteur } \\
\text { Merieux } \\
\text { Connaug- } \\
\text { ht } \\
\text { (Toronto, } \\
\text { Canada) }\end{array}$ & $2 \times 10^{7} \mathrm{CFU}$ & $\begin{array}{l}24 \text { patients } \\
\text { with stage } \\
\text { III or IV }\end{array}$ & GD3 ganglioside + BCG & $\begin{array}{r}\text { Intradermal } \\
\text { injection }\end{array}$ & $\begin{array}{l}-42 \% \text { of patients developed anti-GD3 } \\
\text { antibodies, but this response did not corre- } \\
\text { late with survival outcomes. } \\
\text {-There was no significant difference in } \\
\text { survival between responders and } \\
\text { nonresponders }\end{array}$ & $\begin{array}{l}\text { Chapman } \\
\text { et al. } \\
\text { (2004) }\end{array}$ \\
\hline \multirow[t]{2}{*}{$\begin{array}{l}\text { BCG } \\
\text { (Instituto } \\
\text { Malbran) } \\
\text { (Buenos } \\
\text { Aires, } \\
\text { Argentin- } \\
\text { a) }\end{array}$} & $2 \times 10^{6} \mathrm{CFU}$ & $\begin{array}{l}20 \text { patients } \\
\text { with stages } \\
\text { IIB and IV }\end{array}$ & $\begin{array}{l}\text { *VACCIMEL and BCG as } \\
\text { adjuvant GM-CSF } \\
\text { VACCIMEL + GM-CSF } \\
\text { rhGM-CSF (recombinant } \\
\text { human } \\
\text { granulocyte-monocyte } \\
\text { colony-stimulating factor) }\end{array}$ & $\begin{array}{r}\text { Intradermal } \\
\text { injection }\end{array}$ & $\begin{array}{l}\text {-The systemic toxicity of VACCIMEL, BCG, } \\
\text { and rhGM-CSF was mild } \\
\text {-Regression of metastatic lesions was not } \\
\text { observed }\end{array}$ & $\begin{array}{l}\text { Barrio } \\
\quad \text { et al. } \\
\quad(2006)\end{array}$ \\
\hline & & $\begin{array}{l}9 \text { patients with } \\
\text { stage III }\end{array}$ & $\begin{array}{l}\text { Intralesional Bacillus } \\
\text { Calmette-Guerin }\end{array}$ & $\begin{array}{r}\text { Intradermal } \\
\text { injection }\end{array}$ & -The combination therapy was well tolerated & $\begin{array}{l}\text { Kidner } \\
\text { et al. }\end{array}$ \\
\hline
\end{tabular}


Table 1 (continued)

\begin{tabular}{|c|c|c|c|c|c|c|}
\hline BCG strain & BCG dose & Population & Drug/vaccine & $\begin{array}{l}\text { BCG } \\
\text { administration }\end{array}$ & Main results & Reference \\
\hline $\begin{array}{l}\text { ILBCG/i- } \\
\text { miquimod } \\
\text { treatment }\end{array}$ & $\begin{array}{l}3 \times 10^{6} \mathrm{CFU} \text { and } \\
1.5 \times 10^{6} \mathrm{CFU} 2 \\
\text { weeks later }\end{array}$ & & $\begin{array}{l}\text { (ILBCG) and topical 5\% } \\
\text { imiquimod cream }\end{array}$ & & $\begin{array}{l}-78 \% \text { patients did not develop recurrent } \\
\text { in-transit disease }\end{array}$ & (2012) \\
\hline $\begin{array}{l}\text { BCG } \\
\text { (Shanghai } \\
\text { Institute } \\
\text { of } \\
\text { Biologic- } \\
\text { al } \\
\text { Products } \\
\text { Co., Ltd., } \\
\text { Shanghai, } \\
\text { China) }\end{array}$ & BCG $(150 \mathrm{mg} / \mathrm{kg})$ & $\begin{array}{l}\text { C57BL/6 } \\
\text { female mice } \\
\text { (mouse } \\
\text { melanoma } \\
\text { model) }\end{array}$ & $\begin{array}{l}\text { *Human mucin } 1 \text { (MUC1) } \\
\text { *Maltose-binding protein } \\
\quad(\mathrm{MBP}) \\
\text { MBP } \\
\text { MUC1 } \\
\text { BCG } \\
\text { (MUC1/BCG) } \\
\text { MUC1-MBP } \\
\text { (MUC1-MBP/BCG) }\end{array}$ & $\begin{array}{l}\text { Subcutaneous } \\
\text { injection }\end{array}$ & $\begin{array}{l}\text {-MBP and BCG alone were found to induce } \\
\text { NK cell activity } \\
\text {-MUC1-MBP/BCG synergistically induced } \\
\text { NK cell activity } \\
\text {-Immunization with MUC1/BCG and } \\
\text { MUC1-MBP induced lower levels of IgG1 } \\
\text { and significantly higher levels of IgG2c } \\
\text { compared with MUC1 }\end{array}$ & $\begin{array}{l}\text { Fang et al. } \\
\quad \text { (2014) }\end{array}$ \\
\hline Tice & $\begin{array}{l}3 \text { million CFU and } \\
1.5 \text { million } \mathrm{CFU} \\
2 \text { weeks later }\end{array}$ & $\begin{array}{l}3 \text { patients with } \\
\text { in-transit } \\
\text { melanoma } \\
\text { (ITM) }\end{array}$ & $\begin{array}{l}\text { Intralesional Bacillus } \\
\text { Calmette-Guerin } \\
\text { (ILBCG) and/or topical } \\
\text { imiquimod. }\end{array}$ & $\begin{array}{l}\text { Intralesional } \\
\text { injection }\end{array}$ & $\begin{array}{l}\text {-The ILBCG monotherapy was not sufficient } \\
\text { to cause disease regression, but } 3 \text { years and } \\
11 \text { months later, } 1 \text { patient remained } \\
\text { disease-free }\end{array}$ & $\begin{array}{l}\text { Kibbi } \\
\text { et al. } \\
\text { (2015) }\end{array}$ \\
\hline $\begin{array}{l}\text { BCG } \\
\text { unknown }\end{array}$ & $10^{6} \mathrm{CFU}$ & $\begin{array}{l}\text { 45-year-old } \\
\text { Caucasian } \\
\text { woman } \\
\text { with stage } \\
\text { III }\end{array}$ & $\begin{array}{l}\text { Mixture of cell lines using } \\
\text { BCG and GM-CSF as ad- } \\
\text { juvants }\end{array}$ & $\begin{array}{r}\text { Intradermal } \\
\text { injection }\end{array}$ & $\begin{array}{l}\text {-MART-1 Ag was found throughout the } \\
\text { vaccination site } \\
\text {-Recruitment of Ag-presenting cells and im- } \\
\text { mune response toward the tumor }\end{array}$ & $\begin{array}{r}\text { Aris et al. } \\
\text { (2015) }\end{array}$ \\
\hline $\begin{array}{l}\text { BCG } \\
\quad \text { (Statens } \\
\text { Serum } \\
\text { Institut, } \\
\text { Denmark) }\end{array}$ & $10^{7} \mathrm{CFU}$ & $\begin{array}{l}126 \text { patients } \\
\text { with stage } \\
\text { III }\end{array}$ & $\begin{array}{l}\text { Autologous melanoma cells } \\
\text { conjugated to } \\
\text { dinitrophenyl and mixed } \\
\text { with BCG }\end{array}$ & $\begin{array}{r}\text { Intradermal } \\
\text { injection }\end{array}$ & $\begin{array}{l}\text {-Reduced toxicity of the vaccination and } \\
\text { protective immunity was observed } \\
\text {-Patients with strong delayed-type hypersen- } \\
\text { sitivity (DTH) response showed an overall } \\
\text { survival of } 75 \% \text { compared with } 44 \% \text { in } \\
\text { patients without a strong response }\end{array}$ & $\begin{array}{l}\text { Lotem } \\
\text { et al. } \\
\text { (2016) }\end{array}$ \\
\hline Tice & $\begin{array}{l}\text { BCG doses were } 3 \\
\times 10^{6} \text { CFU on } \\
\text { day } 0 \text { and } 1.5 \times \\
10^{6} \text { CFU on day } \\
14\end{array}$ & $\begin{array}{l}246 \text { patients } \\
\text { with stage } \\
\text { IV }\end{array}$ & $\begin{array}{l}\text { BCG plus CanVaxin vaccine } \\
\text { Canvaxin: three irradiated } \\
\text { whole cells melanoma } \\
\text { lines (M10-VACC, } \\
\text { M24-VACC, and } \\
\text { M101-VACC). }\end{array}$ & $\begin{array}{r}\text { Intradermal } \\
\text { injection }\end{array}$ & $\begin{array}{l}\text {-In the } \mathrm{BCG} / \mathrm{Cv} \text { group, survival was longer in } \\
\text { responders than in nonresponders } \\
\text {-There was no improvement in outcomes } \\
\text { following adjuvant treatment with vaccine } \\
\text { over BCG/placebo }\end{array}$ & $\begin{array}{l}\text { Faries } \\
\quad \text { et al. } \\
\text { (2017) }\end{array}$ \\
\hline Pasteur & $1 \times 10^{6} \mathrm{CFU}$ & $\begin{array}{l}108 \text { patients } \\
\text { with stages } \\
\text { II and III }\end{array}$ & $\begin{array}{l}\text { CSF-470 vaccine plus BCG } \\
\text { and rhGM-CSF }\end{array}$ & $\begin{array}{r}\text { Intradermal } \\
\text { injection }\end{array}$ & $\begin{array}{l}\text {-CSF-470 vaccine plus BCG plus rhGM-CSF } \\
\text { administered as adjuvant therapy was well } \\
\text { tolerated }\end{array}$ & $\begin{array}{l}\text { Mordoh } \\
\text { et al. } \\
\text { (2017) }\end{array}$ \\
\hline $\begin{array}{l}\text { BCG } \\
\text { unknown }\end{array}$ & $160,000 \mathrm{CFU}$ & $\begin{array}{l}12 \text { patients } \\
\text { with stages } \\
\text { IIB, IIC, } \\
\text { and III }\end{array}$ & $\begin{array}{l}\text { CSF-470 vaccine plus BCG } \\
\text { and (rhGM-CSF) }\end{array}$ & $\begin{array}{r}\text { Intradermal } \\
\text { injection }\end{array}$ & $\begin{array}{l}\text {-There was the release of pro-inflammatory } \\
\text { cytokines such as IL-1 } \beta \text { and TNF-a in } \\
\text { some patients } \\
\text {-The vaccination stimulated a long-term cel- } \\
\text { lular and humoral immune response }\end{array}$ & $\begin{array}{l}\text { Pampena } \\
\text { et al. } \\
\text { (2018) }\end{array}$ \\
\hline
\end{tabular}

Additionally, the administration of BEC2, an anti-idiotypic mouse monoclonal antibody that mimics GD3 ganglioside mixed with BCG (BEC2-KLH/BCG) for patients with stage III and IV melanoma resulted in a $78 \%$ survival rate over 28 months (Yao et al. 1999). Furthermore, the GD3 ganglioside can be used as a target for melanoma immunotherapy, showing that 10 patients $(42 \%)$ developed a detectable anti-GD3 antibody response, but did not correlate with survival outcomes (Chapman et al. 2004). It has been reported that BCG is a therapeutic option for stage III in-transit melanoma and can induce chemokine expression and regression of skin lesions (Yang et al. 2017). Another study developed a therapeutic vaccine named CSF-470 for cutaneous melanoma using a mixture of cell lines, BCG, and granulocyte-macrophage colony-stimulating factor (GM-CSF) as adjuvants in phase II-III trials, which resulted in the recruitment of Ag-presenting cells and antitumor immune responses (Aris et al. 2015). Other studies have demonstrated the use of a M-VAX vaccine composed of autologous melanoma cells and BCG that induces interferon-gamma-mediated $\mathrm{T}$ cell triggering inflammatory responses (Carretero et al. 2008).

The use of autologous melanoma vaccines and BCG plus recombinant human GM-CSF (rhGM-CSF) for treatment of stage IV melanoma has been shown to result in a complete response in $10 \%$ of patients with a median survival of 232 days (Leong et al. 1999). One such vaccine, VACCINEL, in combination with BCG and rhGM-CSF was administrated to patients with stage IIB/IV melanoma, resulting in well-tolerated, mildly toxic effects and increased antitumor immune responses (Barrio et al. 2006). Similar studies using the 
CSF-470 vaccine in combination with BCG and rhGM-CSF were well tolerated (Mordoh et al. 2017) and induced the release of pro-inflammatory cytokines such as IL- $1 \beta$ and TNF- $\alpha$, stimulating long-term cellular and humoral immune responses (Pampena et al. 2018). On the other hand, Lotem et al. (2016) observed that the use of an autologous melanoma vaccine conjugated to dinitrophenyl and mixed with BCG in patients with stage III melanoma, followed by administration of ipilimumab, increased the response rate to $46 \%$ compared with $19 \%$ of patients treated with ipilimumab alone.

The continued generation of recombinant fusion proteins for use in melanoma immunotherapy is important as MUC1 and maltose-binding protein (MBP) in combination with $\mathrm{BCG}$ induces a specific cellular immunity, synergistic activities, $\mathrm{NK}$ cell activity, and increased expression of IFN- $\gamma$ and IgG2c (Fang et al. 2014).

\section{BCG in melanoma immunotherapy}

Recently, immunotherapeutic strategies have been used in cancer therapy to activate the immune system and destroy cancer cells. While the antitumor mechanism of BCG has not been clearly elucidated, BCG has been used as a nonspecific immune stimulant to induce long-lasting immune responses (Wada et al. 1996). Indeed, different tumor immunization strategies and molecularly targeted therapies against the MAPK pathway are being studied to improve the response rate and survival for advanced melanoma patients (Davar et al. 2012). However, in order to translate these novel therapies to clinical practice, a better understanding of melanoma pathogenesis, its interaction between cancer and immune cells, and the genetic alterations resulting in targetable melanoma-associated antigens (i.e., neoantigens), such as MART-1 (Melan-A), gp100, and tyrosinase (Schumacher and Schreiber 2015; Cervinkova et al. 2017), is required. By utilizing vaccination strategies to increase the number of detectable neoantigens, we may be able to improve recognition of tumor cells by CD8+ T cells, circumventing the immune escape mechanism utilized by the tumor cells (Ragupathi et al. 2000; Terando et al. 2007), increasing tumor cell killing and reducing metastases (Lau et al. 2001; Hepner et al. 2017).

Vaccine development with a BCG adjuvant can induce immune responses contributing to antitumor immunity through the recruitment the $\mathrm{NK}, \mathrm{CD}^{+}$, and $\mathrm{CD}^{+} \mathrm{T}$ cells (Murphy et al. 1993; Kim and Cantor 2014; Kaufmann et al. 2016), resulting in the release of cytokines into the tumor microenvironment (Lardone et al. 2017). BCG-stimulated DCs secretes higher levels of TNF- $\alpha$, IFN- $\gamma$, and IL-12p40 (Lalor et al. 2010; Kumar and Bhaskar 2019).

BCG causes the nonspecific identification of pathogenassociated molecular patterns (PAMPs) by TLR2, TLR4, TLR8, and TLR9, triggering an inflammatory cascade that results in the activation of macrophages (Mantovani and Sica 2010; Iqbal and Hussain 2014; Velmurugan et al. 2016), dendritic cells (Tsuji et al. 2000), and NK cells (Brandau et al. 2001; Kleinnijenhuis et al. 2014). BCG can also increase TRAIL expression and activation of TLR4 and TLR2 in neutrophils, triggering cancer cell apoptosis and improving melanoma patient responses (Ludwig et al. 2004).

It has been shown that the use of BCG as an immunotherapy agent for melanoma can result in tumor regression (Morton et al. 1976) and that topical or intratumoral injection of BCG induces immune cell infiltration and enhances the long-lasting expression of chemokines and cytokines, including CXCL9, CXCL10, CXCL11, IL-15, TNF- $\alpha$, and IFN- $\gamma$ (Yang et al. 2017). Due to the high levels of tumor heterogeneity observed clinically and relatively low immunogenicity of melanoma-associated antigens, immunotherapeutic strategies for melanoma utilizing rBCG strains capable of secreting functional cytokines that can stimulate antitumor immune responses show great promise (Sanlorenzo et al. 2014).

The development of recombinant BCG ( $\mathrm{rBCG}$ ) strains has resulted in new vaccines, capable of delivering different antigens that trigger induction of CD8 $\mathrm{T}$ cell immune responses with long-lasting memory compared with conventional systems (da Costa et al. 2014; Liang et al. 2015; Oliveira et al. 2017). Also, these rBCG strains have been genetically modified to display different phenotypes, for example through the utilization of Hsp60, Hsp7, pAN, and 18-kDa promoters (Newton-Foot and Gey Van Pittius 2013; Oliveira et al. 2017) that increase cytokine expression and enhance immune responses (Himmelrich et al. 2000; Slobbe et al. 1999). The use of different rBCG strains secreting a variety of cytokines such as IL-4, IL-6, IL-2, IFN- $\gamma$, and GM-CSF can modify and potentially improve the antitumor response (Murray et al. 1996; Zhou et al. 2015).

In addition, this method also allows for the development of auxotrophic strains, including strain, where genes involved in the synthesis of metabolites are deleted, strains without antibiotic resistance markers, and strains displaying stable expression both in vitro or in vivo (Borsuk et al. 2007; Seixas et al. 2010; Rizzi et al. 2017).

Several studies have reported the administration of $\mathrm{rBCG}$ strains for melanoma treatment (Table 2). One of the most common rBCG strains used for anticancer therapy is $\mathrm{rBCG}$ strains expressing interleukin-2 (rBCG-IL-2) and GM-CSF (rBCG-GM-CSF). These combinations increase the production of INF- $\gamma$, cytokine important for inhibiting tumor cell growth (Fujimoto et al. 1996).

One of the most important strains used is a Pasteur strain, which contains the heat shock protein 60 (hsp60) promoter controlling the expression of IL-2. When administered by intratumoral injection, this rBCG strain displayed immunomodulatory properties and resulted in a $45 \%$ reduction in tumor size in a murine B16 melanoma model (C57BL/6 mice) 
(Duda et al. 1995). In addition, rBCG can express recombinant human interferon-alpha $2 \mathrm{~B}$ (rhIFN- $\alpha$ ) under control of the hsp60 promoter, resulting in increased IFN- $\gamma$ production and immunostimulatory properties (Luo et al. 2001).

\section{Conclusion}

This review summarizes the used of wild-type and various rBCG strains as therapeutic agents for melanoma to induce immunomodulatory activities and enhance antitumor immune responses, as well as its combination with chemotherapy and immunotherapy agents. Few rBCG constructs have been explored and little is known about the immunological basis and mechanisms of action leading to BCG-induced melanoma cell killing. Further investigation of these mechanisms of action will allow for the development of improved treatment strategies to improve the survival of MM patients.

Funding information This study was financed in part by the Coordenação de Aperfeiçoamento de Pessoal de Nível Superior - Brasil (CAPES) - Finance Code 001 and Conselho Nacional de Desenvolvimento Científico e Tecnológico (CNPq)

\section{Compliance with ethical standards}

Conflict of interest The authors declare that they have no conflict of interest.

Ethical approval This article does not contain any studies with human participants or animals performed by any of the authors.

\section{References}

Abbasi NR, Shaw HM, Rigel DS, Friedman RJ, McCarthy WH, Osman I, Kopf AW, Polsky D (2004) Early diagnosis of cutaneous melanoma. Jama 292:2771. https://doi.org/10.1001/jama.292.22.2771

Abildgaard C, Guldberg P (2015) Molecular drivers of cellular metabolic reprogramming in melanoma. Trends Mol Med 21:164-171. https:// doi.org/10.1016/j.molmed.2014.12.007

Agarwala SS, Neuberg D, Park Y, Kirkwood JM (2004) Mature results of a phase III randomized trial of Bacillus Calmette-Guerin (BCG) versus observation and BCG plus Dacarbazine versus BCG in the adjuvant therapy of American Joint Committee on cancer stage I-III melanoma (E1673): a trial of the Eastern Coop. Cancer 100:16921698. https://doi.org/10.1002/cncr.20166

Ahn JJ, Ghandour RA, McKiernan JM (2014) New agents for Bacillus Calmette-Guérin-refractory nonmuscle invasive bladder cancer. Curr Opin Urol 24:540-545. https://doi.org/10.1097/MOU. 0000000000000088

Albertini MR (2018) The age of enlightenment in melanoma immunotherapy. J Immunother Cancer 6:4-7. https://doi.org/10.1186/ s40425-018-0397-8

Alegre E, Sanmamed MF, Rodriguez C, Carranza O, Martín-Algarra S, González Á (2014) Study of circulating microRNA-125b levels in serum exosomes in advanced melanoma. Arch Pathol Lab Med 138: 828-832. https://doi.org/10.5858/arpa.2013-0134-AO 
Ali Z, Yousaf N, Larkin J (2013) Melanoma epidemiology, biology and prognosis. Eur J Cancer Suppl 11:81-91. https://doi.org/10.1016/j. ejcsup.2013.07.012

Aris M, Bravo AI, Barrio MM, Mordoh J (2015) Inoculation site from a cutaneous melanoma patient treated with an allogeneic therapeutic vaccine : a case report 6:1-5. doi: https://doi.org/10.3389/fimmu. 2015.00144

Arnold M, Vries E de, Whiteman DC, Jemal A, Bray F, Parkin DM, Soerjomataram I (2018) Global burden of cutaneous melanoma attributable to ultraviolet radiation in 2012. 1314:1305-1314 . doi: https://doi.org/10.1002/ijc.31527

Arulananda S, Blackley E, Cebon J (2018) Review of immunotherapy in melanoma. Cancer Forum 42:17-23

Askeland EJ, Newton MR, O'Donnell MA, Luo Y (2012) Bladder cancer immunotherapy: BCG and beyond. Ther Adv Urol 2012:1-13. https://doi.org/10.1155/2012/181987

Balch CM, Gershenwald JE, Soong SJ, Thompson JF, Atkins MB, Byrd DR, Buzaid AC, Cochran AJ, Coit DG, Ding S, Eggermont AM, Flaherty KT, Gimotty PA, Kirkwood JM, McMasters KM, Mihm MC Jr, Morton DL, Ross MI, Sober AJSV (2009) Final version of 2009 AJCC melanoma staging and classification. J Clin Oncol 27: 6199-6206. https://doi.org/10.1200/jco.2009.23.4799

Bandarchi B, Ma L, Navab R, Seth A, Rasty G (2010) From melanocyte to metastatic malignant melanoma. Dermatol Res Pract. https://doi. org $/ 10.1155 / 2010 / 583748$

Barrio MM, de Motta PT, Kaplan J, von Euw EM, Bravo AI, Chacon RD, Mordoh J (2006) A phase I study of an allogeneic cell vaccine (VACCIMEL) with GM-CSF in melanoma patients. J Immunother 29:444-454

Bastian BC (2014) The molecular pathology of melanoma: an integrated taxonomy of melanocytic neoplasia. Annu Rev Pathol 9:239-271. https://doi.org/10.1146/annurev-pathol-012513-104658

Bastos RG, Borsuk S, Seixas FK, Dellagostin OA (2009) Recombinant Mycobacterium bovis BCG. Vaccine 27:6495-6503. https://doi.org/ 10.1016/j.vaccine.2009.08.044

Bedikian AY, Richards J, Kharkevitch D, Atkins MB, Whitman E, Gonzalez R (2010) A phase 2 study of high-dose Allovectin-7 in patients with advanced metastatic melanoma. Melanoma Res 20: 218-226. https://doi.org/10.1097/CMR.0b013e3283390711

Begnini KR, Rizzi C, Campos VF, Borsuk S, Schultze E, Yurgel VC, Nedel F, Dellagostin OA, Collares T, Seixas FK (2013) Auxotrophic recombinant Mycobacterium bovis BCG overexpressing Ag85B enhances cytotoxicity on superficial bladder cancer cells in vitro. Appl Microbiol Biotechnol 97:1543-1552. https://doi.org/10.1007/ s00253-012-4416-2

Begnini KR, Buss JH, Collares T, Seixas FK (2015) Recombinant Mycobacterium bovis BCG for immunotherapy in nonmuscle invasive bladder cancer. Appl Microbiol Biotechnol 99:3741-3754. https://doi.org/10.1007/s00253-015-6495-3

Bhatia S, Tykodi SS, Thompson JA (2009) Treatment of metastatic melanoma: an overview. Oncology (Williston Park) 23:488-496

Biet F, Kremer L, Wolowczuk I, Delacre M, Locht C (2002) Mycobacterium bovis BCG producing Interleukin-18 increases antigen-specific gamma interferon production in mice. Infect Immun 70:6549-6557. https://doi.org/10.1128/IAI.70.12.65496557.2002

Bishop JN, Bataille V, Gavin A, Lens M, Marsden J, Mathews TWC (2007) The prevention, diagnosis, referral and management of melanoma of the skin. Clin Med 7:283-290

Borsuk S, Mendum TA, Fagundes MQ, Michelon M, Cunha CW, McFadden J, Dellagostin OA (2007) Auxotrophic complementation as a selectable marker for stable expression of foreign antigens in Mycobacterium bovis BCG. Tuberculosis 87:474-480. https://doi. org/10.1016/j.tube.2007.07.006

Bougnoux AC, Solassol J (2013) The contribution of proteomics to the identification of biomarkers for cutaneous malignant melanoma.
Clin Biochem 46:518-523. https://doi.org/10.1016/j.clinbiochem. 2012.12.011

Brandau S, Riemensberger J, Jacobsen M, Kemp D, Zhao W, Zhao X, Jocham D, Ratliff TL, Bhle A (2001) NK cells are essential for effective BCG immunotherapy. Int J Cancer 92:697-702. https:// doi.org/10.1002/1097-0215(20010601)92:5<697::AID-IJC1245>3. $0 . \mathrm{CO} ; 2-\mathrm{Z}$

Brandner JM, Haass NK (2013) Melanoma's connections to the tumour microenvironment. Pathology 45:443-452. https://doi.org/10.1097/ PAT.0b013e328363b3bd

Broussard L, Howland A, Ryu S, Song K, Norris D, Armstrong CA, Song PI (2018) Melanoma cell death mechanisms. Chonnam Med J 54: 135. https://doi.org/10.4068/cmj.2018.54.3.135

Callahan MK, Kluger H, Postow MA, Segal NH, Lesokhin A, Atkins MB, Kirkwood JM, Krishnan S, Bhore R, Horak C, Wolchok JD, Sznol M (2018) Nivolumab plus ipilimumab in patients with advanced melanoma: updated survival, response, and safety data in a phase I dose-escalation study. J Clin Oncol 36:391-398. https://doi. org/10.1200/JCO.2017.72.2850

Cananzi FCM, Mudan S, Dunne M, Belonwu N, Dalgleish AG (2013) Long-term survival and outcome of patients originally given Mycobacterium vaccae for metastatic malignant melanoma. Hum Vaccin Immunother 9:2427-2433. https://doi.org/10.4161/hv.25618

Carretero R, Romero JM, Ruiz-Cabello F, Maleno I, Rodriguez F, Camacho FM, Real LM, Garrido F, Cabrera T (2008) Analysis of HLA class I expression in progressing and regressing metastatic melanoma lesions after immunotherapy. Immunogenetics 60:439447. https://doi.org/10.1007/s00251-008-0303-5

Cascinelli N, Rümke P, MacKie R, Morabito A, Bufalino R (1989) The significance of conversion of skin reactivity to efficacy of bacillus Calmette-Guérin (BCG) vaccinations given immediately after radical surgery in stage II melanoma patients. Cancer Immunol Immunother 28:282-286. https://doi.org/10.1007/BF00205238

Cervinkova M, Kucerova P, Cizkova J (2017) Spontaneous regression of malignant melanoma - Is it based on the interplay between host immune system and melanoma antigens? Anti-Cancer Drugs 28: 819-830. https://doi.org/10.1097/CAD.0000000000000526

Chapman PB, Wu D, Ragupathi G, Lu S, Williams L, Hwu WJ, Johnson DLP (2004) Sequential immunization of melanoma patients with GD3 ganglioside vaccine and anti-idiotypic monoclonal antibody that mimics GD3 ganglioside. Clin Cancer Res 10:4717-4723

Chapman R, Stutz H, Jacobs W, Shephard E, Williamson AL (2013) Priming with recombinant auxotrophic BCG expressing HIV-1 Gag, RT and Gp120 and boosting with recombinant MVA induces a robust $\mathrm{T}$ Cell response in mice. PLoS One 8:. doi: https://doi.org/ 10.1371/journal.pone.0071601

Ciudad-Blanco C, Avilés-Izquierdo JA, Lázaro-Ochaita P, SuárezFernández R (2014) Dermoscopic findings for the early detection of melanoma: an analysis of 200 cases. Actas Dermosifiliogr 105: 683-693. https://doi.org/10.1016/j.adengl.2014.07.015

Costanzi JJ, Al-Sarraf M, Groppe C, Bottomley R, Fabian C, Neidhart JDD (1982) Combination chemotherapy plus levamisole in the treatment of disseminated malignant melanoma a southwest oncology group study. Cancer 53:833-836. https://doi.org/10.1002/10970142(19840215)53:4<833::AID-CNCR2820530402>3.0.CO;2-\#

Curtin JA, Fridlyand J, Kageshita T, Patel HN, Busam KJ, Kutzner H, Cho KH, Aiba S, Bröcker EB, LeBoit PE, Pinkel DBB (2005) Distinct sets of genetic alterations in melanoma. N Engl J Med 353:2135-2147. https://doi.org/10.1056/nejmoa050092

Da Costa AC, Nogueira SV, Kipnis A, Junqueira-Kipnis AP (2014) Recombinant BCG: innovations on an old vaccine. Scope of BCG strains and strategies to improve long-lasting memory. Front Immunol 5:1-9. https://doi.org/10.3389/fimmu.2014.00152

Davar D, Tarhini AA, Kirkwood JM (2012) Adjuvant therapy for melanoma. Cancer J:192-202. https://doi.org/10.1097/PPO. 0b013e31824f118b 
Desel C, Dorhoi A, Bandermann S, Grode L, Eisele B, Kaufmann SHE (2011) Recombinant BCG $\Delta$ ureC hly+ induces superior protection over parental BCG by stimulating a balanced combination of type 1 and type 17 cytokine responses. J Infect Dis 204:1573-1584. https:// doi.org/10.1093/infdis/jir592

Dietrich G, Viret JF, Hess J (2003) Mycobacterium bovis BCG-based vaccines against tuberculosis: novel developments. Vaccine 21: 667-670. https://doi.org/10.1016/S0264-410X(02)00577-7

DiFronzo LA, Gupta RK, Essner R, Foshag LJ, O’Day SJ, Wanek LA, Stern SL, Morton DL (2002) Enhanced humoral immune response correlates with improved disease-free and overall survival in American Joint Committee on cancer stage II melanoma patients receiving adjuvant polyvalent vaccine. J Clin Oncol 20:32423248. https://doi.org/10.1200/JCO.2002.01.065

Donin NM, Lenis AT, Holden S, Drakaki A, Pantuck A, Belldegrun A, Chamie K (2017) Immunotherapy for the treatment of urothelial carcinoma. J Urol 197:14-22. https://doi.org/10.1016/j.juro.2016. 02.3005

Duda RB, Yang H, Dooley DD, Abu-jawdeh G (1995) Recombinant BCG therapy suppresses melanoma tumor growth 2:542-549. doi: https://doi.org/10.1007/bf02307089

Fang F, Ma J, Ni W, Wang F, Sun X, Li Y, Li Q, Xie F, Wang J, Zhai R, Liu Z, Gao S, Tai G (2014) MUC1 and maltose-binding protein recombinant fusion protein combined with Bacillus CalmetteGuerin induces MUC1-specific and nonspecific anti-tumor immunity in mice. Mol Med Rep 10:1056-1064. https://doi.org/10.3892/ mmr.2014.2306

Faries MB, Mozzillo N, Kashani-Sabet M, Thompson JF, Kelley MC, DeConti RC, Lee JE, Huth JF, Wagner J, Dalgleish A, Pertschuk D, Nardo C, Stern S, Elashoff R, Gammon G, Morton DL (2017) Longterm survival after complete surgical resection and adjuvant immunotherapy for distant melanoma metastases. Ann Surg Oncol 24: 3991-4000. https://doi.org/10.1245/s10434-017-6072-3b

Findeisen P, Zapatka M, Peccerella T, Matzk H, Neumaier M, Schadendorf D, Ugurel S (2009) Serum amyloid A as a prognostic marker in melanoma identified by proteomic profiling. J Clin Oncol 27:2199-2208. https://doi.org/10.1200/JCO.2008.18.0554

Finn L, Markovic SN, Joseph RW (2012) Therapy for metastatic melanoma : the past, present, and future. BMC Med 10:23. https://doi. org/10.1186/1741-7015-10-23

Flaherty KT, McArthur G (2010) BRAF, a target in melanoma. Cancer 116:4902-4913. https://doi.org/10.1002/cncr.25261

Fujimoto T, Donnell MAO, Szilvasi A, Yang H, Duda RB (1996) Bacillus Calmette-Guérin plus interleukin-2 and/or granulocyte/ macrophage-colony-stimulating factor enhances immunocompetent cell production of interferon-g, which inhibits B16F10 melanoma cell growth in vitro. Cancer Immunol Immunother 42:280-284. https://doi.org/10.1007/s002620050283

Gallagher RP, Lee TK (2006) Adverse effects of ultraviolet radiation : a brief review 92:119-131. doi: https://doi.org/10.1016/j.pbiomolbio. 2006.02.011

Gallagher RP, Spinelli JJ, Lee TK (2005) Tanning beds, sunlamps, and risk of cutaneous malignant melanomalr10.1158/1055-9965.EPI04-0564. Cancer Epidemiol Biomark Prev 14:562-566. https://doi. org/10.1158/1055-9965.EPI-04-0564

Garbe C, Eigentler TK, Keilholz U, Hauschild A, Kirkwood JM (2011) Systematic review of medical treatment in melanoma: current status and future prospects. Oncologist 16:5-24. https://doi.org/10.1634/ theoncologist.2010-0190

Garnett MJ, Marais R (2004) Guilty as charged: B-RAF is a human oncogene. Cancer Cell 6:313-319. https://doi.org/10.1016/j.ccr. 2004.09.022

Gazzé G (2018) Combination therapy for metastatic melanoma: a pharmacist's role, drug interactions \& complementary alternative therapies. Melanoma Manag 5:MMT07. https://doi.org/10.2217/mmt2017-0026
Goldstein BGA (2001) Diagnosis and management of malignant melanoma. Am Fam Physician 63:1359-1368

Gonzalez R, Hutchins L, Nemunaitis J, Atkins M, Schwarzenberger PO (2006) Phase 2 trial of Allovectin-7 in advanced metastatic melanoma. Melanoma Res 16:521-526. https://doi.org/10.1097/01.cmr. 0000232299.44902 .41

Gorski DH, Alsina J, Mann B, Shih W, Kim HJ, Gabriel EM, Goydos JS, Germino FJ (2005) Detection of B-RAF and N-RAS mutations in human melanoma. J Am Coll Surg 200:362-370. https://doi.org/10. 1016/j.jamcollsurg.2004.10.032

Griewank KG, Scolyer RA, Thompson JF, Flaherty KT, Schadendorf D, Murali R (2014) Genetic alterations and personalized medicine in melanoma: progress and future prospects J Natl Cancer Inst 106. doi: https://doi.org/10.1093/jnci/djt435

Gurzu S, Beleaua MA, Jung I (2018) The role of tumor microenvironment in development and progression of malignant melanomas - a systematic review. Romanian J Morphol Embryol 59:23-28

Haass NK, Smalley KSM, Herlyn M (2004) The role of altered cell-cell communication in melanoma progression. J Mol Histol 35:309-318. https://doi.org/10.1023/B:HIJO.0000032362.35354.bb

Halder K, Banerjee S, Ghosh S, Bose A, Das S, Chowdhury BP, Majumdar S (2017) Mycobacterium indicus pranii (Mw) inhibits invasion by reducing matrix metalloproteinase (MMP-9) via AKT/ ERK-1/2 and PKC $\alpha$ signaling: a potential candidate in melanoma cancer therapy. Cancer Biol Ther 18:850-862. https://doi.org/10. 1080/15384047.2015.1078024

Hart PDA, Sutherland IAN (1977) BCG and vole bacillus vaccines in the prevention of tuberculosis in adolescence and early adult life final report to the Medical Research Council. Public Health Rep 293-295

Hauschild A, Grob JJ, Demidov LV, Jouary T, Gutzmer R, Millward M, Rutkowski P, Blank CU, Miller WH, Kaempgen E, Martín-Algarra S, Karaszewska B, Mauch C, Chiarion-Sileni V, Martin AM, Swann S, Haney P, Mirakhur B, Guckert ME, Goodman V, Chapman PB (2012) Dabrafenib in BRAF-mutated metastatic melanoma: a multicentre, open-label, phase 3 randomised controlled trial. Lancet 380:358-365. https://doi.org/10.1016/S0140-6736(12) 60868-X

Hayashi D, Takii T, Fujiwara N, Fujita Y, Yano I, Yamamoto S, Kondo M, Yasuda E, Inagaki E, Kanai K, Fujiwara A, Kawarazaki A, Chiba T, Onozaki K (2009) Comparable studies of immunostimulating activities in vitro among Mycobacterium bovis bacillus Calmette-Guérin (BCG) substrains. FEMS Immunol Med Microbiol 56:116-128. https://doi.org/10.1111/j.1574-695X.2009.00559.x

Heakal Y, Kester M, Savage S (2011) Vemurafenib (PLX4032): Un inhibidor de BRAF mutado disponible por vía oral para el tratamiento del melanoma metastático. Ann Pharmacother 45: 1399-1405. https://doi.org/10.1345/aph.1Q363

Hepner A, Salgues A, Garicochea B, Sahade M, Dos Anjos C, Sahade M, Camargo V, Garicochea B, Shoushtari A, Postow M, Fernandes GMR (2017) Treatment of advanced melanoma - a changing landscape. Rev Assoc Med Bras 63:814-823. https://doi.org/10.1590/ 1806-9282.63.09.814

Himmelrich H, Lo-Man R, Winter N, Guermonprez P, Sedlik C, Rojas M, Monnaie D, Gheorghiu M, Lagranderie M, Hofnung M, Gicquel B, Clément JM, Leclerc C (2000) Immune responses induced by recombinant BCG strains according to level of production of a foreign antigen: MalE. Vaccine 18:2636-2647. https://doi.org/10.1016/ S0264-410X(00)00070-0

Hodi FS, Chesney J, Pavlick AC, Robert C, Grossmann KF, McDermott DF, Linette GP, Meyer N, Giguere JK, Agarwala SS, Shaheen M, Ernstoff MS, Minor DR, Salama AK, Taylor MH, Ott PA, Horak C, Gagnier P, Jiang J, Wolchok JD, Postow MA (2016) Combined nivolumab and ipilimumab versus ipilimumab alone in patients with advanced melanoma: 2-year overall survival outcomes in a multicentre, randomised, controlled, phase 2 trial. Lancet Oncol 17:1558-1568. https://doi.org/10.1016/S1470-2045(16)30366-7 
Hodis E, Watson IR, Kryukov GV, Arold ST, Imielinski M, Theurillat JP, Nickerson E, Auclair D, Li L, Place C, Dicara D, Ramos AH, Lawrence MS, Cibulskis K, Sivachenko A, Voet D, Saksena G, Stransky N, Onofrio RC, Winckler W, Ardlie K, Wagle N, Wargo J, Ch CL (2012) A landscape of driver mutations in melanoma. Cell 150:251-263. https://doi.org/10.1016/j.cell.2012.06.024

Hogan SA, Levesque MP, Cheng PF (2018) Melanoma immunotherapy: next-generation biomarkers. Front Oncol 8:1-10. https://doi.org/10. 3389/fonc. 2018.00178

Hsueh EC, Essner R, Foshag LJ, Ollila DW, Gammon G, O’Day SJ, Boasberg PD, Stern SL, Ye X, Morton DL (2002) Prolonged survival after complete resection of disseminated melanoma and active immunotherapy with a therapeutic cancer vaccine. J Clin Oncol 20: 4549-4554. https://doi.org/10.1200/JCO.2002.01.151

Hsueh EC, Famatiga E, Shu S, Ye X, Morton DL (2004) Peripheral blood CD4+ T-cell response before postoperative active immunotherapy correlates with clinical outcome in metastatic melanoma. Ann Surg Oncol 11:892-899. https://doi.org/10.1245/ASO.2004.02.018

Iqbal NT, Hussain R (2014) Non-specific immunity of BCG vaccine: a perspective of BCG immunotherapy. Trials Vaccinol 3:143-149. https://doi.org/10.1016/j.trivac.2014.08.002

Kaufmann E, Spohr C, Battenfeld S, De Paepe D, Holzhauser T, Balks E, Homolka S, Reiling N, Gilleron M, Bastian M (2016) BCG vaccination induces robust CD4+ $\mathrm{T}$ cell responses to Mycobacterium tuberculosis complex-specific lipopeptides in Guinea pigs. J Immunol 196:2723-2732. https://doi.org/10.4049/jimmunol. 1502307

Kibbi N, Ariyan S, Faries M, Choi JN (2015) Treatment of in-transit melanoma with intralesional Bacillus Calmette-Guérin (BCG) and topical imiquimod 5\% cream: a report of 3 cases. J Immunother 38: 371-375. https://doi.org/10.1097/CJI.0000000000000098

Kidner TB, Morton DL, Lee DJ, Hoban M, Foshag LJ, Turner RR, Faries MB (2012) Combined intralesional bacille calmette-guérin (BCG) and topical imiquimod for in-transit melanoma. J Immunother 35: 716-720. https://doi.org/10.1097/CJI.0b013e31827457bd

Kim H-J, Cantor H (2014) CD4 T-cell subsets and tumor immunity: the helpful and the not-so-helpful. Cancer Immunol Res 2:91-98. https://doi.org/10.1158/2326-6066.cir-13-0216

Kleinnijenhuis J, Quintin J, Preijers F, Joosten LA, Jacobs C, Xavier RJ, van der Meer JW, van Crevel RNM (2014) BCG-induced trained immunity in NK cells: role for non-specific protection to infection. Clin Immunol 155:213-219. https://doi.org/10.1016/j.clim.2014.10. 005

Kölmel KF, Grange JM, Krone B, Mastrangelo G, Rossi CR, Henz BM, Seebacher C, Botev IN, Niin M, Lambert D, Shafir R, Kokoschka EM, Kleeberg UR, Gefeller O, Pfahlberg A (2005) Prior immunisation of patients with malignant melanoma with vaccinia or BCG is associated with better survival. An European Organization for Research and Treatment of Cancer cohort study on 542 patients. Eur J Cancer 41:118-125. https://doi.org/10.1016/ j.ejca.2004.09.023

Koya MP, Simon MA, Soloway MS (2006) Complications of intravesical therapy for urothelial cancer of the bladder. J Urol 175:2004-2010. https://doi.org/10.1016/S0022-5347(06)00264-3

Kresowik TP, Griffith TS (2009) Bacillus Calmette-Guerin immunotherapy for urothelial carcinoma of the bladder. Immunotherapy 1:281288. https://doi.org/10.2217/1750743X.1.2.281

Kumar P, Bhaskar S (2019) Myeloid differentiation primary response protein 88 (MyD88)-deficient dendritic cells exhibit a skewed cytokine response to BCG. BMC Res Notes 12:12-15. https://doi.org/ 10.1186/s13104-019-4086-6

Lalor MK, Smith SG, Floyd S, Gorak-Stolinska P, Weir RE, Blitz R, Branson K, Fine PE, Dockrell HM (2010) Complex cytokine profiles induced by BCG vaccination in UK infants. Vaccine 28:16351641. https://doi.org/10.1016/j.vaccine.2009.11.004
Lardone RD, Chan AA, Lee AF, Foshag LJ, Faries MB, Sieling PA, Lee DJ (2017) Mycobacterium bovis Bacillus Calmette-Guérin alters melanoma microenvironment favoring antitumor $\mathrm{T}$ cell responses and improving M2 macrophage function. Front Immunol 8:1-14. https://doi.org/10.3389/fimmu.2017.00965

Lattanzi M, Lee Y, Simpson D, Moran U, Darvishian F, Kim RH, Hernando E, Polsky D, Hanniford D, Shapiro R, Berman R, Pavlick AC, Wilson MA, Kirchhoff T, Weber JS, Zhong J, Osman I (2019) Primary melanoma histologic subtype: impact on survival and response to therapy. J Natl Cancer Inst 111:180-188. https://doi. org/10.1093/jnci/djy086

Lattime EC (1992) Murine bladder carcinoma cells present antigen to BCG-specific CD4+ T-cells. Cancer Res 52:4286-4290

Lau R, Wang F, Jeffery G, Marty V, Kuniyoshi J, Bade E, Ryback ME, Weber J (2001) Phase I trial of intravenous peptide-pulsed dendritic cells in patients with metastatic melanoma. J Immunother 24:66-78. https://doi.org/10.1097/00002371-200101000-00008

Leong SPL (2003) Future perspectives on malignant melanoma. Surg Clin North Am 83:453-456. https://doi.org/10.1016/S00396109(02)00204-9

Leong SP, Enders-Zohr P, Zhou YM, Stuntebeck S, Habib FA, Allen RE Jr, Sagebiel RW, Glassberg AB, Lowenberg DWHF (1999) Recombinant human granulocyte macrophage-colony stimulating factor (rhGM-CSF) and autologous melanoma vaccine mediate tumor regression in patients with metastatic melanoma. J Immunother 22:166-174. https://doi.org/10.1097/00002371-199903000-00008

Leung AS, Tran V, Wu Z, Yu X, Alexander DC, Gao GF, Zhu B, Liu J (2008) Novel genome polymorphisms in BCG vaccine strains and impact on efficacy. BMC Genomics 9:1-12. https://doi.org/10.1186/ 1471-2164-9-413

Liang J, Teng X, Yuan X, Zhang Y, Shi C, Yue T, Zhou L, Li J, Fan X (2015) Enhanced and durable protective immune responses induced by a cocktail of recombinant BCG strains expressing antigens of multistage of Mycobacterium tuberculosis. Mol Immunol 66:392401. https://doi.org/10.1016/j.molimm.2015.04.017

Liu J, Tran V, Leung AS, Alexander DC, Zhu B (2009) BCG vaccines: their mechanisms of attenuation and impact on safety and protective efficacy. Hum Vaccin 5:70-78. https://doi.org/10.4161/hv.5.2.7210

Liu W, Xu Y, Shen H, Yan J, Yang E, Wang H (2017) Recombinant bacille Calmette-Guérin coexpressing Ag85b-IFN- $\gamma$ enhances the cell-mediated immunity in c57bl/6 mice. Exp Ther Med 13:23392347. https://doi.org/10.3892/etm.2017.4273

Long GV, Menzies AM, Nagrial AM, Haydu LE, Hamilton AL, Mann GJ, Hughes TM, Thompson JF, Scolyer RA, Kefford RF (2011) Prognostic and clinicopathologic associations of oncogenic BRAF in metastatic melanoma. J Clin Oncol 29:1239-1246. https://doi. org/10.1200/JCO.2010.32.4327

Lotem M, Peretz T, Drize O, Gimmon Z, Ad El D, Weitzen R, Goldberg H, Ben David I, Prus D, Hamburger T, Shiloni E (2002) Autologous cell vaccine as a post operative adjuvant treatment for high-risk melanoma patients (AJCC stages III and IV). The new American Joint Committee on Cancer. Br J Cancer 86:1534-1539. https://doi. org $/ 10.1038 / \mathrm{sj} / \mathrm{bjc} / 6600251$

Lotem M, Merims S, Frank S, Hamburger T, Nissan A, Kadouri L, Cohen J, Straussman R, Eisenberg G, Frankenburg S, Carmon E, Alaiyan B, Shneibaum S, Ozge Ayyildiz Z, Isbilen M, Mert Senses K, Ron I, Steinberg H, Smith Y, Shiloni E, Gure AO, Peretz T (2016) Adjuvant autologous melanoma vaccine for macroscopic stage III disease: survival, biomarkers, and improved response to CTLA-4 blockade. J Immunol Res 2016:1-12. https://doi.org/10.1155/ 2016/8121985

Lovly CM, Dahlman KB, Fohn LE, Su Z, Dias-santagata D, Hicks DJ, Hucks D, Berry E, Terry C, Duke M, Su Y, Sobolik-delmaire T, Richmond A, Kelley MC, Vnencak-jones CL, Iafrate AJ, Sosman J, Pao W (2012) Routine multiplex mutational profiling of 
melanomas enables enrollment in genotype-driven therapeutic trials 7: . doi: https://doi.org/10.1371/journal.pone.0035309

Ludwig AT, Moore JM, Luo Y, Chen X, Saltsgaver NA, O'Donnell MA, Griffith TS (2004) Tumor necrosis factor-related apoptosis-inducing ligand: a novel mechanism for Bacillus Calmette-Guérin-induced antitumor activity. Cancer Res 64:3386-3390. https://doi.org/10. 1158/0008-5472.CAN-04-0374

Luo Y, Chen X, Han R, O'Donnell MA (2001) Recombinant bacille Calmette-Guérin (BCG) expressing human interferon-alpha 2B demonstrates enhanced immunogenicity. Clin Exp Immunol 123: 264-270. https://doi.org/10.1046/j.1365-2249.2001.01428.x

Luo Y, Chen X, O'Donnell MA (2003) Role of Th1 and Th2 cytokines in BCG-induced IFN- $\gamma$ production: cytokine promotion and simulation of BCG effect. Cytokine 21:17-26. https://doi.org/10.1016/ S1043-4666(02)00490-8

Luo Y, Yamada H, Chen X, Ryan AA, Evanoff DP, Triccas JA, O'Donnell MA (2004) Recombinant Mycobacterium bovis bacillus Calmette-Guérin (BCG) expressing mouse IL-18 augmente Th1 immunity and macrophage cytotoxicity. Clin Exp Immunol 137:24 34. https://doi.org/10.1111/j.1365-2249.2004.02522.x

Luo W, Qu Z, Zhang L, Xie Y, Luo F, Tan Y, Pan Q, Zhang XL (2018) Recombinant BCG::Rv2645 elicits enhanced protective immunity compared to BCG in vivo with induced ISGylation-related genes and Th1 and Th17 responses. Vaccine 36:2998-3009. https://doi. org/10.1016/j.vaccine.2018.04.025

Luther C, Swami U, Zhang J, Milhem M, Zakharia Y (2019) Advanced stage melanoma therapies: detailing the present and exploring the future. Crit Rev Oncol Hematol 133:99-111. https://doi.org/10. 1016/j.critrevonc.2018.11.002

Mantovani A, Sica A (2010) Macrophages, innate immunity and cancer: balance, tolerance, and diversity. Curr Opin Immunol 22:231-237. https://doi.org/10.1016/j.coi.2010.01.009

Maruf M, Brancato SJ, Agarwal PK (2016) Nonmuscle invasive bladder cancer: a primer on immunotherapyNonmuscle invasive bladder cancer: a primer on immunotherapy. Cancer Biol Med 13:194205. https://doi.org/10.20892/j.issn.2095-3941.2016.0020

Mattia G, Puglisi R, Ascione B, Malorni W, Carè A, Matarrese P (2018) Cell death-based treatments of melanoma : conventional treatments and new therapeutic strategies. Cell Death Dis 9:112. https://doi.org/ 10.1038/s41419-017-0059-7

Meyskens FL Jr (1982) Studies of retinoids in the prevention and treatment of cancer. J Am Acad Dermatol 6:824-830. https://doi.org/10. 1016/S0190-9622(82)70072-6

Mitchell MS (2003) Immunotherapy as part of combinations for the treatment of cancer. Int Immunopharmacol 3:1051-1059. https://doi.org/ 10.1016/S1567-5769(03)00019-5

Miyazaki J, Kawai K, Oikawa T, Johraku A, Hattori K, Shimazui T, Akaza H (2006) Uroepithelial cells can directly respond to Mycobacterium bovis bacillus Calmette-Guérin through Toll-like receptor signalling. BJU Int 97:860-864. https://doi.org/10.1111/j. 1464-410X.2006.06026.x

Morales A, Herr H, Steinberg G, Given R, Cohen Z, Amrhein J, Kamat AM (2015) Efficacy and safety of MCNA in patients with nonmuscle invasive bladder cancer at high risk for recurrence and progression after failed treatment with bacillus Calmette-Guérin. J Urol 193:1135-1143. https://doi.org/10.1016/j.juro.2014.09.109

Mordoh J, Pampena MB, Aris M, Blanco PA, Lombardo M, von Euw EM, Mac KS, Crow MY, Bravo AI, O'Connor JM, Orlando AG, Ramello F, Levy EM, Barrio MM (2017) Phase II study of adjuvant immunotherapy with the CSF-470 vaccine plus Bacillus CalmetteGuerin plus recombinant human granulocyte macrophage-colony stimulating factor vs medium-dose Interferon alpha $2 \mathrm{~B}$ in stages IIB, IIC, and III cutaneous melanoma patients: a single institution, randomized study. Front Immunol 8:1-15. https://doi.org/10.3389/ fimmu.2017.00625
Morton DL, Eilber FR, Holmes EC, Sparks FC, Ramming KP (1976) Present status of BCG immunotherapy of malignant melanoma. Cancer Immunol Immunother 1:93-98. https://doi.org/10.1007/ BF00205300

Murphy G, Radu A, Kaminer M, Berd D (1993) Autologous melanoma vaccine induces inflammatory responses in melanoma metastases: relevance to immunologic regression and immunotherapy. J Invest Dermatol 100:335S-341S. https://doi.org/10.1038/jid.1993.59

Murray PJ, Aldovini A, Young RA (1996) Manipulation and potentiation of antimycobacterial immunity using recombinant bacille CalmetteGuerin strains that secrete cytokines. Proc Natl Acad Sci 93:934 939. https://doi.org/10.1073/pnas.93.2.934

Naoe M, Ogawa Y, Takeshita K, Morita J, Iwamoto S, Miyazaki A, Yoshida H (2007) Bacillus Calmette-Guérin-pulsed dendritic cells stimulate natural killer T cells and $\gamma \delta \mathrm{T}$ cells. Int J Urol 14:532-538. https://doi.org/10.1111/j.1442-2042.2006.01697.x

Newton-Foot M, Gey Van Pittius NC (2013) The complex architecture of mycobacterial promoters. Tuberculosis 93:60-74. https://doi.org/10. 1016/j.tube.2012.08.003

Nieuwenhuizen NE, Kulkarni PS, Shaligram U, Cotton MF, Rentsch CA, Eisele B, Grode L, Kaufmann SHE (2017) The recombinant bacille Calmette-Guérin vaccine VPM1002: ready for clinical efficacy testing. Front Immunol 8:1-9. https://doi.org/10.3389/fimmu.2017. 01147

Nikolaev SI, Rimoldi D, Iseli C, Valsesia A, Robyr D, Gehrig C, Harshman K, Guipponi M, Bukach O, Zoete V, Michielin O, Muehlethaler K, Speiser D, Beckmann JS, Xenarios I, Halazonetis TD, Jongeneel CV, Stevenson BJ, Antonarakis SE (2012) Exome sequencing identifies recurrent somatic MAP2K1 and MAP2K2 mutations in melanoma. Nat Genet 44:133-139. https://doi.org/10. 1038/ng.1026

Oliveira TL, Rizzi C, Dellagostin OA (2017) Recombinant BCG vaccines: molecular features and their influence in the expression of foreign genes. Appl Microbiol Biotechnol 101:6865-6877. https:// doi.org/10.1007/s00253-017-8439-6

Olszanski AJ (2014) Current and future roles of targeted therapy and immunotherapy in advanced melanoma. J Manag Care Pharm 20: 346-356. https://doi.org/10.18553/jmcp.2014.20.4.346

Orgaz JL, Sanz-Moreno V (2013) Emerging molecular targets in melanoma invasion and metastasis. Pigment Cell Melanoma Res 26:3957. https://doi.org/10.1111/pcmr.12041

Pampena MB, Cartar HC, Cueto GR, Levy EM, Blanco PA, Barrio MM, Mordoh J (2018) Dissecting the immune stimulation promoted by CSF-470 vaccine plus adjuvants in cutaneous melanoma patients: long term antitumor immunity and short term release of acute inflammatory reactants. Front Immunol 9:1-12. https://doi.org/10. 3389/fimmu.2018.02531

Potrony M, Badenas C, Aguilera P, Puig-Butille JA, Carrera C, Malvehy J, Puig S (2015) Update in genetic susceptibility in melanoma. Ann Transl Med 3:210. https://doi.org/10.3978/j.issn.2305-5839.2015. 08.11

Puig S, Malvehy J, Badenas C, Ruiz A, Jimenez D, Cuellar F, Azon A, Gonzàlez U, Castel T, Campoy A, Herrero J, Martí R, Brunet-Vidal $\mathrm{J}$, Milà M (2005) Role of the CDKN2A locus in patients with multiple primary melanomas. J Clin Oncol 23:3043-3051. https://doi. org/10.1200/JCO.2005.08.034

Ragupathi G, Meyers M, Adluri S, Howard L, Musselli C, Livingston PO (2000) Induction of antibodies against GD3 ganglioside in melanoma patients by vaccination with GD3-lactone-KLH conjugate plus immunological adjuvant QS-21. Int J Cancer 85:659-666. https:// doi.org/10.1002/(SICI)1097-0215(20000301)85:5<659::AIDIJC11>3.0.CO;2-5

Redelman-Sidi G, Iyer G, Solit DB, Glickman MS (2013) Oncogenic activation of Pak1-dependent pathway of macropinocytosis determines BCG entry into bladder cancer cells. Cancer Res 73:11561167. https://doi.org/10.1158/0008-5472.CAN-12-1882 
Ribas A, Gogas H, Flaherty KT, Middleton MR, Sondak VK, Kirkwood JM, Hersey P (2011) New challenges in endpoints for drug development in advanced melanoma. Clin Cancer Res 18:336-341. https://doi.org/10.1158/1078-0432.ccr-11-2323

Ribas A, Hamid O, Daud A, Hodi FS, Wolchok JD, Kefford R, Joshua AM, Patnaik A, Hwu W, Weber JS, Gangadhar TC, Hersey P, Dronca R, Joseph RW, Zarour H, Chmielowski B, Lawrence DP, Algazi A, Rizvi NA, Hoffner B, Mateus C, Gergich K, Lindia JA, Giannotti M, Li XN, Ebbinghaus S, Kang SP, Robert C (2016) Association of Pembrolizumab with tumor response and survival among patients with advanced melanoma 1782:1600-1609. doi: https://doi.org/10.1001/jama.2016.4059

Rizzi C, Peiter AC, Oliveira TL, Seixas Neto ACP, Leal KS, Hartwig DD, Seixas FK, Borsuk S, Dellagostin OA (2017) Stable expression of Mycobacterium bovis antigen 85B in auxotrophic $\mathrm{m}$. Bovis bacillus calmette-guérin. Mem Inst Oswaldo Cruz 112:123-130. https://doi. org/10.1590/0074-02760160360

Roskoski R (2010) RAF protein-serine/threonine kinases: structure and regulation. Biochem Biophys Res Commun 399:313-317. https:// doi.org/10.1016/j.bbrc.2010.07.092

Saiga H, Nieuwenhuizen N, Gengenbacher M, Koehler AB, Schuerer S, Moura-Alves P, Wagner I, Mollenkopf HJ, Dorhoi A, Kaufmann SHE (2015) The recombinant BCG $\Delta$ ureC::hly vaccine targets the AIM2 inflammasome to induce autophagy and inflammation. J Infect Dis 211:1831-1841. https://doi.org/10.1093/infdis/jiu675

Sanlorenzo M, Vujic I, Posch C, Dajee A, Yen A, Kim S, Ashworth M, Rosenblum MD, Algazi A, Osella-Abate S, Quaglino P, Daud A, Ortiz-Urda S (2014) Melanoma immunotherapy. Cancer Biol Ther 15:665-674. https://doi.org/10.4161/cbt.28555

Schadendorf D, Algarra SM, Bastholt L, Cinat G, Dreno B, Eggermont AMM, Espinosa E, Guo J, Hauschild A, Petrella T, Schachter J, Hersey P (2009) Immunotherapy of distant metastatic disease. Ann Oncol 20:41-50. https://doi.org/10.1093/annonc/mdp253

Schumacher T, Schreiber R (2015) Neoantigens in cancer immunotherapy. Science 348:69-74. https://doi.org/10.1126/science.aaa4971

Schwartzentruber D, Lawson D, Richards J, Conry R, Miller D, Treisman J, Gailani F, Riley L, Conlon K, Pockaj B, Kendra K, White R, Gonzalez R, Kuzel T, Curti B, Leming P, Whitman E, Balkissoon J, Reintgen D, Kaufman H, Marincola F, Merino M, Rosenberg S, Choyke P, Vena D, Hwu P (2011) gp100 peptide vaccine and interleukin-2 in patients with advanced melanoma. N Engl J Med 364:2119-2127. https://doi.org/10.1056/NEJMoa1012863.gp100

Secanella-Fandos S, Luquin M, Julián E (2013) Connaught and russian strains showed the highest direct antitumor effects of different bacillus calmette-guérin substrains. J Urol 189:711-718. https://doi.org/ 10.1016/j.juro.2012.09.049

Seixas FK, Borsuk S, Fagundes MQ, Hartwig DD, Cerqueira GM, Dellagostin OA (2010) Stable expression of Leptospira interrogans antigens in. Biol Res 43:13-18. doi: /S0716-97602010000100003

Shinozaki M, O'day SJ, Kitago M, Amersi F, Kuo C, Kim J, Wang H-J, Hoon DSB (2007) Utility of circulating B-RAF DNA mutation in serum for monitoring melanoma patients receiving biochemotherapy. The management of cutaneous melanoma continues to pose a 53:2068-2075 . doi: https://doi.org/10.1158/10780432.CCR-06-2120

Shtivelman E, Davies MA, Hwu P, Yang J, Lotem M, Oren M, Flaherty KT, Fisher DE (2014) Pathways and therapeutic targets in melanoma. Oncotarget 5:1701-1752. https://doi.org/10.18632/oncotarget. 1892

Siegel RL, Miller KD, Jemal A (2019) Cancer statistics, 2019. CA Cancer J Clin 69:7-34. https://doi.org/10.3322/caac.21551

Simeone E, Ascierto PA (2017) Anti-PD-1 and PD-L1 antibodies in metastatic melanoma. Melanoma Manag 4:175-178. https://doi.org/10. 2217/mmt-2017-0018

Slobbe L, Lockhart E, O'Donnell MA, Mackintosh C, De Lisle G, Buchan G (1999) An in vivo comparison of bacillus Calmette-
Guerin (BCG) and cytokine- secreting BCG vaccines. Immunology 96:517-523. https://doi.org/10.1046/j.1365-2567. 1999.00702.x

Sloot S, Rashid OM, Sarnaik AA, Zager JS (2016) Developments in intralesional therapy for metastatic melanoma. Cancer Control 23: 12-20. https://doi.org/10.1177/107327481602300104

Smith FO, Goff SL, Klapper JA, Levy C, Allen T, Mavroukakis SA, Rosenberg SA (2007) Risk of bowel perforation in patients receiving interleukin-2 after therapy with anti-CTLA 4 monoclonal antibody. J Immunother 30:130. https://doi.org/10.1097/01.cji. 0000211334.06762 .89

Srivastava N, McDermott D (2014) Update on benefit of immunotherapy and targeted therapy in melanoma: the changing landscape. Cancer Manag Res 6:279-289. https://doi.org/10.2147/cmar.s64979

Stark MS, Woods SL, Gartside MG, Bonazzi VF, Dutton-Regester K, Aoude LG, Chow D, Sereduk C, Niemi NM, Tang N, Ellis JJ, Reid J, Zismann V, Tyagi S, Muzny D, Newsham I, Wu Y, Palmer JM, Pollak T, Youngkin D, Brooks BR, Lanagan C, Schmidt CW, Kobe B, MacKeigan JP, Yin H, Brown KM, Gibbs R, Trent J, Hayward NK (2012) Frequent somatic mutations in MAP3K5 and MAP3K9 in metastatic melanoma identified by exome sequencing. Nat Genet 44:165-169. https://doi.org/10.1038/ng.1041

Stewart JH, Levine EA (2011) Role of bacillus Calmette-Guérin in the treatment of advanced melanoma. Expert Rev Anticancer Ther 11: 1671-1676. https://doi.org/10.1586/era.11.163

Sullivan RJ, Flaherty KT (2014) Major therapeutic developments and current challenges in advanced melanoma. Br J Dermatol 170:3644. https://doi.org/10.1111/bjd.12698

Sullivan RJ, Atkins MB, Kirkwood JM, Agarwala SS, Clark JI, Ernstoff MS, Fecher L, Gajewski TF, Gastman B, Lawson DH, Lutzky J, McDermott DF, Margolin KA, Mehnert JM, Pavlick AC, Richards JM, Rubin KM, Sharfman W, Silverstein S, Slingluff CL, Sondak VK, Tarhini AA, Thompson JA, Urba WJ, White RL, Whitman ED, Hodi FS, Kaufman HL (2018) An update on the Society for Immunotherapy of Cancer consensus statement on tumor immunotherapy for the treatment of cutaneous melanoma: version 2.0. J Immunother Cancer 6:1-23. https://doi.org/10.1186/s40425-0180362-6

Suttmann H, Riemensberger J, Bentien G, Schmaltz D, Sto M, Jocham D, Bo A, Brandau S (2006) Neutrophil granulocytes are required for effective Bacillus Calmette-Guerin immunotherapy of bladder cancer and orchestrate local immune responses. 8250-8258. doi: https:// doi.org/10.1158/0008-5472.CAN-06-1416

Terando AM, Faries MB, Morton DL (2007) Vaccine therapy for melanoma: current status and future directions. Vaccine 25:B4-16. doi: https://doi.org/10.1016/j.vaccine.2007.06.033

Triozzi P, Tuthill R, Borden E (2011) Re-inventing intratumoral immunotherapy for melanoma. Immunotherapy 3:653-671. https://doi. org/10.2217/imt.11.46

Tsioulias GJ, Gupta RK, Tisman G, Hsueh EC, Essner R, Wanek LA, Morton DL (2001) Serum TA90 antigen-antibody complex as a surrogate marker for the efficacy of a polyvalent allogeneic wholecell vaccine (CancerVax) in melanoma. Ann Surg Oncol 8:198-203. https://doi.org/10.1245/aso.2001.8.3.198

Tsuji S, Matsumoto M, Takeuchi O, Akira S, Azuma I, Hayashi A, Toyoshima K, Seya T (2000) Maturation of human dendritic cells by cell wall skeleton of Mycobacterium bovis bacillus CalmetteGuérin: involvement of toll-like receptors. Infect Immun 68:68836890. https://doi.org/10.1128/IAI.68.12.6883-6890.2000

Velmurugan R, Challa DK, Ram S, Ober RJ, Ward ES (2016) Macrophage-mediated trogocytosis leads to death of antibodyopsonized tumor cells. Mol Cancer Ther 15:1879-1889. https:// doi.org/10.1158/1535-7163.MCT-15-0335

Veronesi U, Aubert C, Bajetta E, Beretta G, Bonadonna G, Cascinelli N, De Marsillac J, Ikonopisov R, Kiss B, Krementz T, Lejeune F, Mechl Z, Milton G, Morabito A, Mulder P, Pawlicki P, Priario J, 
Rumke P, Sertoli R, Tomin R, Trapeznikov N, Wagner R (1984) Controlled study with imidazole carboxamide (DTIC), DTIC + bacillus Calmette-Guerin (BCG), and DTIC + Corynebacterium parvum in advanced malignant melanoma. Tumori 70:41-48. https://doi.org/10.1177/030089168407000107

Wada N, Ohara N, Kameoka M, Nishino Y, Matsumoto S, Nishiyama T, Naito M, Yukitake H, Okada Y, Ikuta K, Yamada T (1996) Longlasting immune response induced by recombinant bacillus CalmetteGuérin (BCG) secretion system. Scand J Immunol 43:202-209. https://doi.org/10.1046/j.1365-3083.1996.d01-28.x

Wolchok JD, van den Eertwegh AJM, Robert C, Akerley W, Schadendorf D, Lutzky J, Weber JS, Hassel JC, Ottensmeier CH, Lorigan P, Hogg D, Peschel C, Haanen JB, O’Day SJ, Gonzalez R, Vaubel JM, Hodi FS, Linette GP, Clark JI, Tian J, Weber RW, McDermott DF, Lebbé C, Urba WJ, Nichol GM, Sosman JA, Hoos A, Quirt I, Yellin MJ (2010) Improved survival with ipilimumab in patients with metastatic melanoma. N Engl J Med 363:711-723

Yang J, Jones MS, Ramos RI, Chan AA, Lee AF, Foshag LJ, Sieling PA, Faries MB, Lee DJ (2017) Insights into local tumor microenvironment immune factors associated with regression of cutaneous melanoma metastases by Mycobacterium bovis Bacille CalmetteGuérin. Front Oncol 7:1-13. https://doi.org/10.3389/fonc.2017. 00061

Yao TJ, Meyers M, Livingston PO, Houghton AN, Chapman PB (1999) Immunization of melanoma patients with BEC2-keyhole limpet hemocyanin plus BCG intradermally followed by intravenous booster immunizations with BEC2 to induce anti-GD3 ganglioside antibodies. Clin Cancer Res 5:77-81

Yuan S, Shi C, Liu L, Han W (2010) MUC1-based recombinant Bacillus Calmette-Guérin vaccines as candidates for breast cancer immunotherapy. Expert Opin Biol Ther 10:1037-1048. https://doi.org/10. $1517 / 14712598.2010 .485185$

Zhao W, Schorey J, Bong-Mastek M, Ritchey J, Brown E, Ratliff T (2000) Role of a Bacillus Calmette-Guérin fibronectin attachment protein in BCG-induced antitumor activity. Int J Cancer 86:83-88

Zheng YQ, Naguib YW, Dong Y, Shi YC, Bou S, Cui Z (2015) Applications of Bacillus Calmette-Guérin and recombinant bacillus Calmette-Guerin in vaccine development and tumor immunotherapy. Expert Rev Vaccines 14:1255-1275. https://doi.org/10.1586/ 14760584.2015.1068124

Zhou Y, Zhao D, Yue R, Khan SH, Shah SZA, Yin X, Yang L, Zhang Z, Zhou X (2015) Inflammasomes-dependent regulation of IL-1 $\beta$ secretion induced by the virulent Mycobacterium bovis Beijing strain in THP-1 macrophages. Antonie Van Leeuwenhoek, Journal of Microbiology 108:163-171. https://doi.org/10.1007/s10482-0150475-6

Publisher's note Springer Nature remains neutral with regard to jurisdictional claims in published maps and institutional affiliations. 